\title{
Iridal-Type Triterpenoids Displaying Human Neutrophil Elastase Inhibition and Anti-Inflammatory Effects from Belamcanda chinensis
}

\author{
Jeong Ho Kim ${ }^{1}$, Yeong Jun Ban ${ }^{1}$, Aizhamal Baiseitova ${ }^{1} \mathbb{D}$, Marie Merci Nyiramana ${ }^{2} \mathbb{D}$, Sang Soo Kang ${ }^{3} \mathbb{D}$, \\ Dawon Kang ${ }^{2, * \mathbb{D}}$ and Ki Hun Park ${ }^{1, *}$
}

1 Division of Applied Life Science (BK21 plus), IALS, Gyeongsang National University, Jinju 52828, Korea; rwg2610@gnu.ac.kr (J.H.K.); banyoung972@naver.com (Y.J.B.); aizhabaiseitova@gmail.com (A.B.)

2 Department of Physiology, College of Medicine and Institute of Health Sciences, Gyeongsang National University, Jinju 52727, Korea; mariemerci1994@naver.com

3 Department of Anatomy, Institute of Health Sciences, College of Medicine, Gyeongsang National University, Jinju 52727, Korea; kangss@gnu.ac.kr

* $\quad$ Correspondence: dawon@gnu.ac.kr (D.K.); khpark@gnu.ac.kr (K.H.P.); Tel.: +82-772-1965 (K.H.P.)

check for

updates

Citation: Kim, J.H.; Ban, Y.J.; Baiseitova, A.; Nyiramana, M.M.; Kang, S.S.; Kang, D.; Park, K.H. Iridal-Type Triterpenoids Displaying Human Neutrophil Elastase Inhibition and Anti-Inflammatory Effects from Belamcanda chinensis. Molecules 2021, 26, 6602. https:// doi.org/10.3390/molecules26216602

Academic Editor: Brullo Chiara

Received: 30 August 2021

Accepted: 29 October 2021

Published: 31 October 2021

Publisher's Note: MDPI stays neutral with regard to jurisdictional claims in published maps and institutional affiliations.

Copyright: (c) 2021 by the authors. Licensee MDPI, Basel, Switzerland. This article is an open access article distributed under the terms and conditions of the Creative Commons Attribution (CC BY) license (https:/ / creativecommons.org/licenses/by/ $4.0 /)$.

\begin{abstract}
The aim of this study is to explore anti-inflammatory phytochemicals from B. chinensis based on the inhibition of pro-inflammatory enzyme, human neutrophil elastase (HNE) and anti-inflammatory activities in lipopolysaccharide (LPS)-stimulated RAW264.7 macrophage. Three stereoisomers of iridal-type triterpenoids (1-3) were isolated from the roots of $B$. chinensis and their stereochemistries were completely identified by NOESY spectra. These compounds were confirmed as reversible noncompetitive inhibitors against $\mathrm{HNE}$ with $\mathrm{IC}_{50}$ values of $6.8-27.0 \mu \mathrm{M}$. The binding affinity experiment proved that iridal-type triterpenoids had only a single binding site to the HNE enzyme. Among them, isoiridogermanal (1) and iridobelamal A (2) displayed significant antiinflammatory effects by suppressing the expressions of pro-inflammatory cytokines, such as iNOS, IL-1 $\beta$, and TNF- $\alpha$ through the NF- $\mathrm{B}$ B pathway in LPS-stimulated RAW264.7 cells. This is the first report that iridal-type triterpenoids are considered responsible phytochemicals for anti-inflammatory effects of B. chinensis.
\end{abstract}

Keywords: B. chinensis; iridal-type triterpenoids; human neutrophil elastase; anti-inflammation

\section{Introduction}

Belamcanda chinensis (L.) DC known as She Gan has been used in Traditional Chinese Medicine (TCM) for the clinical treatment of respiratory diseases including bronchitis, asthma, sore throat and so on [1], which have been listed in Chinese Pharmacopoeia (Committee for the Pharmacopoeia of P.R. China, 2015). B. chinensis belongs to the Iridaceae family and is widely distributed in North America and South-East Asia [2]. The phytochemical constituents of B. chinensis are flavonoids including isoflavones, flavones, and flavonols [3]. Many reports elucidated that isoflavones are major metabolites among phenolic compounds and the uniqueness of this plant is to have triterpenoids with iridal skeleton [4]. This study focused on the phytochemicals which could be attributed to the anti-inflammation potential of B. chinensis, based on human neutrophil elastase (HNE) inhibition and the alleviation effects of the pro-inflammatory cytokines.

Human neutrophil elastase (HNE, EC 3.4.21.37) is a kind of serine protease and is mostly secreted in neutrophil granules of leukocytes in human blood [5]. This enzyme plays a crucial role in the inherent immune system for host defense against pathogen and inflammation [6,7]. The activity of the HNE enzyme is regulated by endogenous serine protease inhibitors, including $\alpha-1$ antitrypsin (AAT), also known as alpha-1 proteinase inhibitor $(\alpha-1 \mathrm{PI})$, to prevent unrestrained proteolysis, which leads to immoderate inflammation in the body [8]. The overexpression of HNE by oxidative stress is associated with 
the increase of the expression of pro-inflammatory cytokines such as interleukin (IL)- $1 \beta$, IL-8, TNF- $\alpha$, and nuclear factor-kappa B (NF- $\mathrm{KB}$ ) [9]. In particular, the activation of NF- $\mathrm{kB}$ leads to its sequestration from the cytoplasm and translocation to the nucleus. It induces the transcription of pro-inflammatory cytokines that stimulate the inflammatory processes [10]. The imbalance between HNE and its regulators causes various chronic diseases such as chronic obstructive pulmonary disease (COPD) [11], atherosclerosis [12], arthritis [13], and liver cirrhosis [14] based on inflammation. Recently, there have been many reports suggesting that HNE inhibitors of medicinal plants are related to anti-inflammatory effects [15-17]. Certainly, anti-inflammation studies are mainly focused on the phytochemicals which could alleviate the inflammatory symptoms induced by oxidative factors. The lead structures of representative anti-inflammatory compounds, including curcumin, resveratrol, epigallocatechin-3-gallate (EGCG), and quercetin [18], belong to phenolics, but there are a few reports on triterpenoids [19].

This study attempts to disclose the anti-inflammatory triterpenoids in the roots of B. chinensis based on pro-inflammatory enzyme (HNE) inhibition and anti-inflammation activities in LPS-stimulated RAW264.7 cells. It included the isolation of phytochemicals, their structural identification, and HNE inhibition. The anti-inflammatory activities of isolated triterpenoids were determined by the suppression of the pro-inflammatory cytokines in LPS-stimulated RAW264.7 cells.

\section{Results and Discussion}

\subsection{Isolation and Identification of Iridal-Type Triterpenoids}

In the activity-guided fractionation of the HNE enzyme, the hexane fraction of the methanol extract showed effective inhibition ( $78 \%$ inhibition, $100 \mu \mathrm{g} / \mathrm{mL}$ ). Four iridal-type triterpenoids were purified from the hexane fraction and their structures were determined by their spectroscopic data (including 2D-NOESY results) and comparison with previous studies [20-22] (Supplementary Materials). Thus, the isolated triterpenoids (1-3) were identified as isoiridogermanal (1), iridobelamal A (2) and iridobelamal B (3), respectively (Figure 1). For example, the most active HNE inhibitory compound 3 was obtained as a colorless oil having the molecular formula $\mathrm{C}_{31} \mathrm{H}_{48} \mathrm{O}_{5}$ and eight degrees of unsaturation, as established by the $[\mathrm{M}+\mathrm{Na}]^{+}$ion at 500.3514 (Calcd. 500.3502) in the HRESIMS. The analysis of degrees of unsaturation indicated dicyclic skeleton with six double bonds. A typical characteristic of the iridal-type triterpenoids, a homofarnesyl group at C-11 of 3 was confirmed by successive connectivity from $\mathrm{H}-11\left(\delta_{\mathrm{H}} 4.88\right)$ to $\mathrm{H}-30\left(\delta_{\mathrm{H}} 1.62\right)$ and HMBC correlations between $\mathrm{C}-11\left(\delta_{\mathrm{C}} 76.2\right)$ and $\mathrm{H}-12\left(\delta_{\mathrm{H}} 5.48\right)$. The lower field quaternary carbon $\left(C-6, \delta_{C}=60.7\right)$ was confirmed as the common atom of a spiro-structure. The Z-configuration of 3 had NOESY relationships of H-1 $\left(\delta_{\mathrm{H}} 10.24\right)$ with $\mathrm{H}-23\left(\delta_{\mathrm{H}} 1.93\right), \mathrm{H}-24$ $\left(\delta_{\mathrm{H}} 1.30\right)$, and $\mathrm{H}-5\left(\delta_{\mathrm{H}} 3.66\right)$. Thus, compound 3 was confirmed as iridobelamal $\mathrm{B}$.
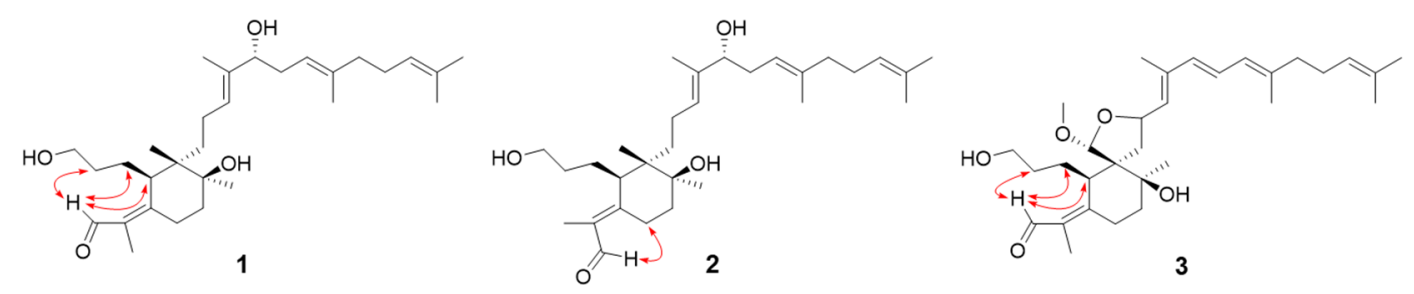

Figure 1. Structures of iridal-type triterpenoids from the roots of B. chinensis and their key NOESY correlations.

\subsection{Human Neutrophil Elastase Inhibition}

Human neutrophil elastase is controlled by its endogenous inhibitors such as $\alpha-1$ antitrypsin, but oxidative stress causes these enzymes to reduce their activities on HNE [23]. It is generally believed that the additional activity of HNE is linked to inflammation [13]. All isolated triterpenoids (1-3) were screened for inhibitory activities against HNE. The inhibitory activity was assayed according to a standard procedure by spectrophotometric 
method using MeOSuc-AAPV- $p$ NA as a substrate. Compounds 1-3 exhibited potent and dose-dependent inhibition against $\mathrm{HNE}$ with $\mathrm{IC}_{50}$ values of 6.8-27.0 $\mu \mathrm{M}$. In particular, all triterpenoids showed a selective inhibition to HNE in comparison with other hydrolases such as $\alpha$-glucosidase, PTP1B, and neuraminidase (Figure $2 \mathrm{a}$ ). This is the first report on the effective inhibitory effect of iridal-type triterpenoids on HNE. The inhibitory activity was affected by subtle changes in structure. The spiro-type compound 3 showed 2-3 fold better inhibition than monocyclic compounds ( $\mathbf{1}$ and $\mathbf{2})$ as shown in Figure $2 \mathrm{~b}$ and Table 1.
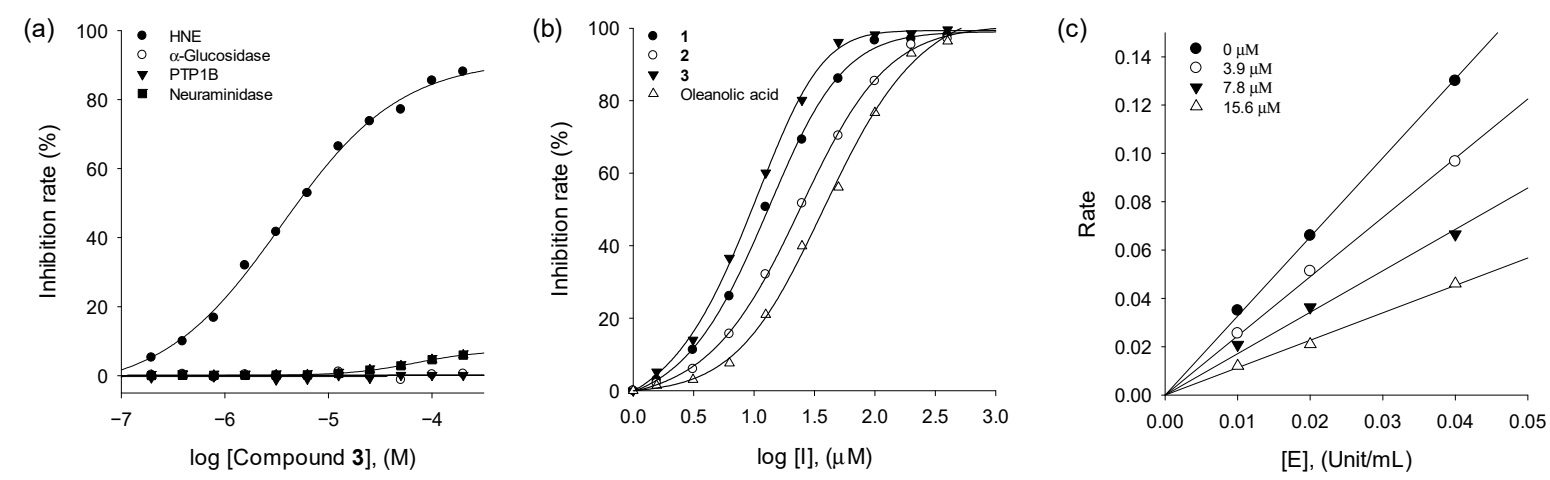

Figure 2. (a) Selectivity of compound 3 on HNE in different hydrolase enzymes. (b) Dose-dependent HNE inhibition by iridal-type triterpenoids (1-3). (c) Determination of the reversible inhibitory mechanism of 3.

Table 1. Inhibitory effects of iridal-type triterpenoids (1-3) on HNE activity.

\begin{tabular}{|c|c|c|}
\hline Compounds & $\mathrm{IC}_{50}{ }^{\mathrm{a}}(\mu \mathrm{M})$ & Type of Inhibition $\left(K_{i}{ }^{b}, \mu M\right)$ \\
\hline 1 & $14.4 \pm 0.3$ & Noncompetitive $(12.7 \pm 0.3)$ \\
\hline 2 & $27.0 \pm 0.6$ & Noncompetitive $(24.9 \pm 0.5)$ \\
\hline 3 & $6.8 \pm 0.3$ & Noncompetitive $(6.2 \pm 0.3)$ \\
\hline Oleanolic acid ${ }^{\mathrm{d}}$ & $38.8 \pm 0.8$ & $\mathrm{NT}^{\mathrm{c}}$ \\
\hline
\end{tabular}

All compounds are tested in three sets of experiments; ${ }^{\mathrm{a}} \mathrm{IC}_{50}$ values of compounds represent the concentration that caused $50 \%$ enzyme activity loss; ${ }^{\mathrm{b}}$ Values of inhibition constant; ${ }^{\mathrm{c}} \mathrm{NT}$ is not tested; ${ }^{\mathrm{d}}$ Oleanolic acid is a positive control.

In a kinetic study, the enzyme activity was measured at various inhibitor concentrations over a series of substrate concentrations. All compounds manifested a similar relationship between enzyme activity and concentrations. The possible kinetic inhibition modes were obtained through double-reciprocal plots of the Michaelis-Menten equation. The reversibility of compound 3 to HNE enzyme was proved by plotting residual enzyme activities versus enzyme concentrations at different concentrations of compound 3, resulting a family of straight lines with a common $y$-axis intercept (Figure 2c). As depicted in Figure $3 c, f$, the inhibition kinetics elucidated by the Lineweaver-Burk plots indicated that compound 3 is a noncompetitive inhibitor. Because increasing the concentration of 3 resulted in a family of lines with a common intercept on the $x$-axis but with different gradients. It illustrated that $V_{\max }$ decreased without change of $K_{\mathrm{m}}$ in the presence of an increasing concentration of 3 . A $K_{\mathrm{i}}$ value of 3 was calculated as $6.2 \mu \mathrm{M}$ by Dixon plots. Other compounds (1 and $\mathbf{2}$ ) also displayed noncompetitive inhibition behaviors (Figure 3).

\subsection{Binding Affinities to Human Neutrophil Elastase}

It is rare that triterpenoids have inhibition activities against the HNE enzyme. Thus, HNE inhibitory activities of compounds (1-3) were doubly confirmed by using the fluorescence (FS) quenching effects based on an enzyme binding affinity. HNE has the intrinsic fluorescence property based on mostly tryptophan residues, Trp-12, Trp-127, and Trp-212 [24]. This fluorescent intensity might be changed by a function of ligand concentration when the enzyme interacts with another ligand. A significant emission was not observed from any of the other components in the assay mixture under the measurement 
conditions $\left(\lambda_{\mathrm{Ex}}=260 \mathrm{~nm}, \lambda_{\mathrm{Em}}=280-400 \mathrm{~nm}\right)$. Figure $4 \mathrm{a}-\mathrm{c}$ showed that the dose-dependent FS quenching effect is proportional to the increase in inhibitor concentration. The FS quenching degrees also accorded closely with inhibitory potencies: $3\left(\mathrm{IC}_{50}=6.8 \mu \mathrm{M}\right) \mathrm{vs}$. $2\left(\mathrm{IC}_{50}=27.0 \mu \mathrm{M}\right)$.
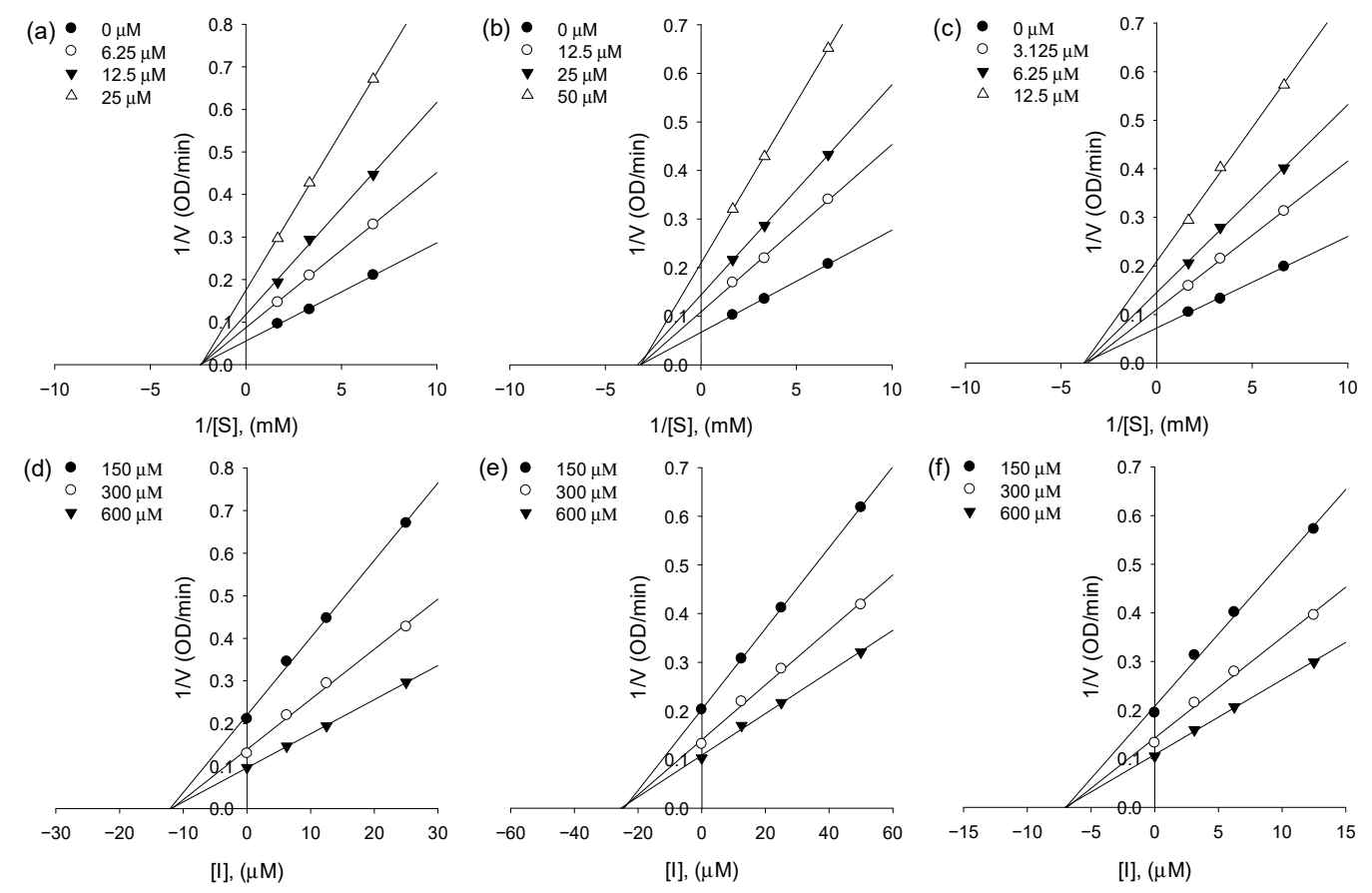

Figure 3. Kinetics and binding affinities of isolated iridal-type triterpenoids on HNE. (a-c) Lineweaver-Burk plots for the effect of 1, 2, and 3 on the HNE. (d-f) Dixon plots for the effect of $\mathbf{1}, \mathbf{2}$, and 3 on the HNE.

The Stern-Volmer quenching constant $\left(K_{\mathrm{sv}}\right)$, the binding constant $\left(K_{\mathrm{A}}\right)$, and the number of binding sites $(n)$ were analyzed in Equations (5) and (6) (Experimental section). The $K_{\mathrm{sv}}$ values were ranked in the following order $\mathbf{3}>\mathbf{1}>\mathbf{2}$, which were essentially in agreement with the order of the inhibitory potencies (Figure $4 \mathrm{~d}$ ). The values of $K_{\mathrm{A}}$ increased from 0.0199 up to $0.0743\left(\times 10^{6} \mathrm{~L} \mathrm{~mol}^{-1}\right)$ by inhibitory potencies (Table 2$)$. The values of $n$ of all inhibitors (1-3) were approximately one (0.97 1.00), indicating that a single binding site exists in HNE for iridal-type triterpenoids.

Table 2. Evaluation of Stern-Volmer constants regarding fluorescence quenching effects of HNE inhibitors 1-3.

\begin{tabular}{cccc}
\hline Compounds & $\boldsymbol{K}_{\mathbf{S V}}{ }^{\mathbf{a}}\left(\times \mathbf{1 0}^{\mathbf{5}} \mathbf{L} \mathbf{~ m o l}^{-\mathbf{1}}\right)$ & $\boldsymbol{K}_{\mathrm{A}}{ }^{\mathbf{b}}\left(\times \mathbf{1 0 ^ { 6 }} \mathbf{L} \mathbf{~ m o l}^{-\mathbf{1}}\right)$ & $\boldsymbol{n}^{\mathbf{c}}$ \\
\hline $\mathbf{1}$ & 0.4166 & 0.0411 & 1.0039 \\
$\mathbf{2}$ & 0.1816 & 0.0199 & 0.9734 \\
$\mathbf{3}$ & 0.6764 & 0.0743 & 0.9727 \\
\hline
\end{tabular}

${ }^{\mathrm{a}} K_{\mathrm{sv}}$ value of each compound represents the Stern-Volmer quenching constant; ${ }^{\mathrm{b}}$ Association constant of the complex of enzyme and quencher; ${ }^{c}$ The number of binding sites of the enzyme.

\subsection{Anti-Inflammatory Effect of Triterpenoid $\mathbf{1}$ and $\mathbf{2}$}

The cytotoxic effects of the triterpenoids (1-3) were measured at various concentrations $(0.1,0.3,1,3$, and $10 \mu \mathrm{g} / \mathrm{mL})$ in RAW264.7 cells for $24 \mathrm{~h}$ using MTT assays. As shown in Figure 5a, the concentrations tested in this study did not induce cell death except for $10 \mu \mathrm{g} / \mathrm{mL}$. Triterpenoids 1 and 2 at a concentration of $10 \mu \mathrm{g} / \mathrm{mL}$ reduced cell viability by $28.8 \pm 4.4 \%$ and $23.4 \pm 5.1 \%$, respectively. To confirm the effect of the triterpenoids 
on the cellular inflammatory condition, 1 and $3 \mu \mathrm{g} / \mathrm{mL}$ concentrations were used in the following experiments.
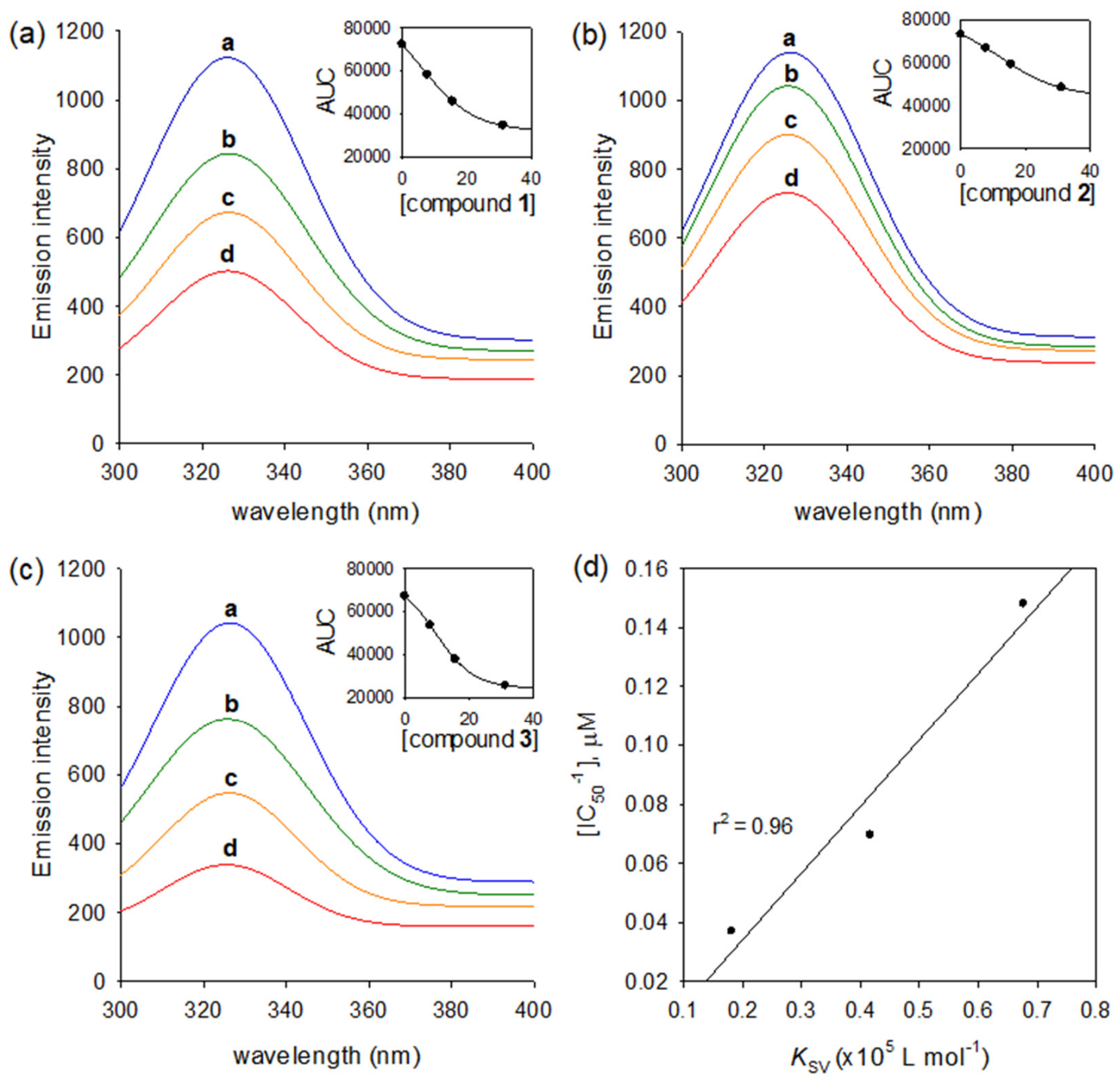

Figure 4. Binding affinities of isolated iridal-type triterpenoids on HNE. (a-c) The fluorescence emission spectra of HNE at different concentrations of compound 1, 2, and $3(0,7.8,15.6$, and $31.2 \mu \mathrm{M}$ for curves from a to d). (d) The correlation between half maximal inhibitory concentration $\left(\mathrm{IC}_{50}\right)$ values and Stern-Volmer constants (Ksv) of compounds 1-3.

LPS, a major component of the outer Gram-negative bacteria membrane, was used to create the cellular inflammatory condition, and LPS-treated RAW264.7 cells secrete a variety of inflammatory mediators [25]. LPS-treated RAW264.7 cells undergo morphological changes, such as cell enlargement, flattening, cellular spreading, and vacuole formation, which indicates that RAW264.7 cells have been activated [26].

Among the four triterpenoids, $\mathbf{1}$ and $\mathbf{2}$ ameliorated the LPS-induced morphological changes in RAW264.7 cells. In treatment, except with LPS, the triterpenoids did not induce 
macrophage activation as shown in Figure 5b. In response to LPS, the mRNA expression level of iNOS and NO production in RAW264.7 cells were stimulated markedly, whereas triterpenoids $\mathbf{1}$ and $\mathbf{2}$ significantly reduced LPS-induced iNOS and NO upregulation $(n=5, p<0.05)$. Furthermore, triterpenoid 2 showed a dose-dependent inhibition at the concentrations of 1 and $3 \mu \mathrm{g} / \mathrm{mL}(n=4, p<0.05$, Figure $5 \mathrm{~d})$. However, these triterpenoids did not influence the expression of the housekeeping gene GAPDH. Because triterpenoids $\mathbf{1}$ and $\mathbf{2}$ were found to inhibit pro-inflammatory mediator NO significantly, we examined their effect on LPS-stimulated pro-inflammatory cytokine signals such as IL-1 $\beta$ and TNF- $\alpha$. As shown in Figure $6 a, b$, the upregulated mRNA levels and the concentrations of IL-1 $\beta$ and TNF- $\alpha$ were noticeably decreased by triterpenoids 1 and 2 . $(n=6, p<0.05)$.

(a)

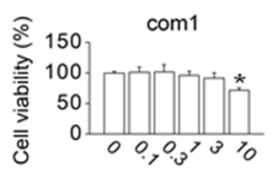

(b)
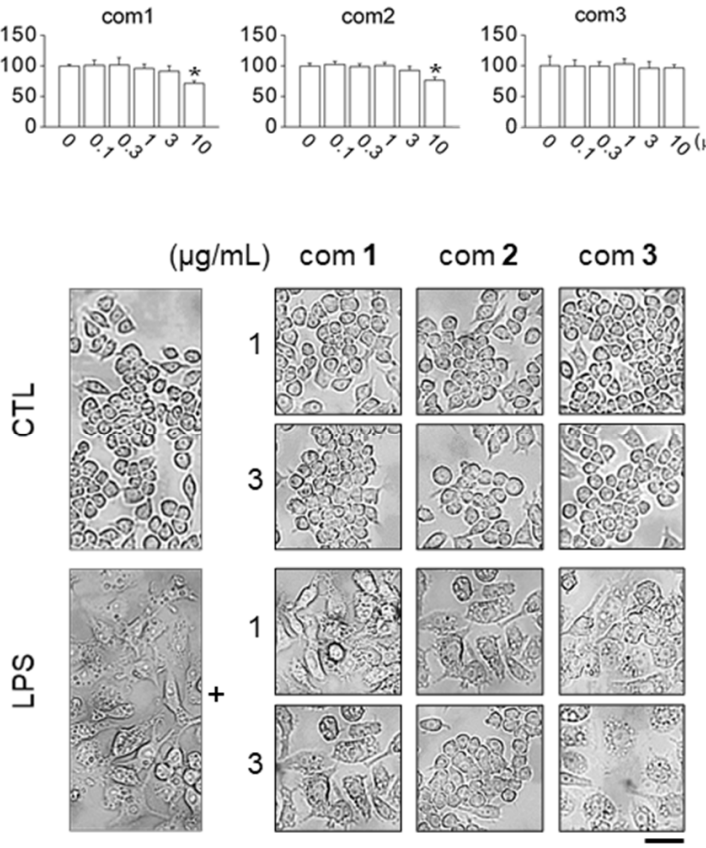

(c)
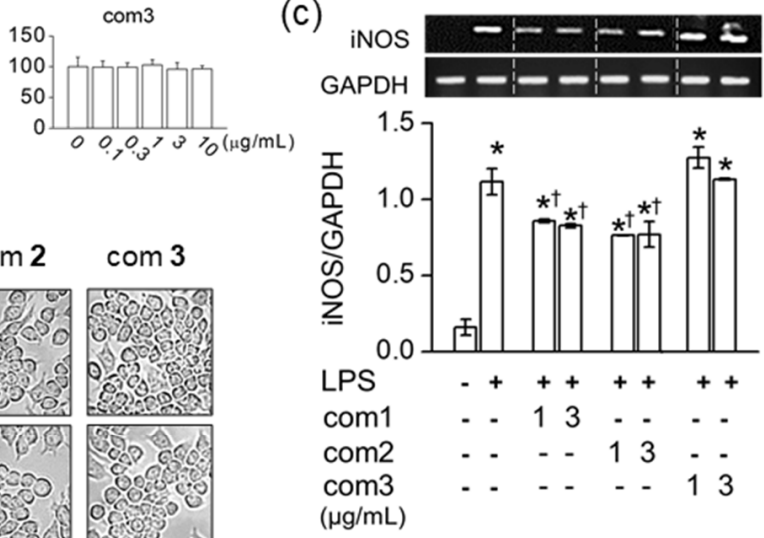

(d)

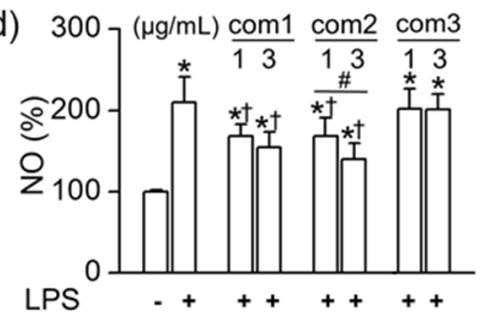

Figure 5. Effects of iridal-type triterpenoids on LPS-stimulated RAW264.7 cells. (a) Effect of the triterpe-noids at different concentrations on the cell viability. (b) Inhibition of LPS-induced macrophage activation by pre-treatment with the triterpenoids. Scale bar, $50 \mu \mathrm{m}$. (c) Inhibition of LPS-induced upregulation of iNOS mRNA expression by the triterpenoids. (d) Inhibition of LPS-induced increase in NO production by the triterpenoids. $(\mathbf{a}, \mathbf{c}, \mathbf{d}) * p<0.05$ compared to control (no treatment with LPS); ${ }^{\dagger} p<0.05$ compared to LPS alone treatment; ${ }^{\#} p<0.05$ compared to the $1 \mu \mathrm{g} / \mathrm{mL}$ of compound 2 .

The NF- $\kappa$ B activation induced by LPS led to the translocation of the NF- $\kappa$ B signal from the cytoplasm to the nucleus. Along with Bay 11-7085, which is the NF- $\mathrm{BB}$ inhibitor, pretreatment with triterpenoids $\mathbf{1}$ and $\mathbf{2}$ suppressed the NF- $\kappa \mathrm{B}$ translocation to the nucleus in the immunocytochemical staining (Figure 6c). In particular, triterpenoid 2 inhibited nuclear translocation of p65 protein, the major subunit of NF- $\kappa \mathrm{B}$, in a dose-dependent manner, as shown in Figure $6 \mathrm{~d}(n=3, p<0.05)$. However, these triterpenoids did not affect the expression of $\beta$-actin and lamin, which are housekeeping proteins of the cells. In summary, triterpenoids 1 and 2 effectively suppressed the expression levels of pro-inflammatory signals such as iNOS, IL-1 $\beta$, and TNF- $\alpha$ by blocking the NF- $\kappa$ B pathway (Figure 6e). Thus, they both had anti-inflammatory potential in LPS-stimulated RAW264.7 cells. 
(a)

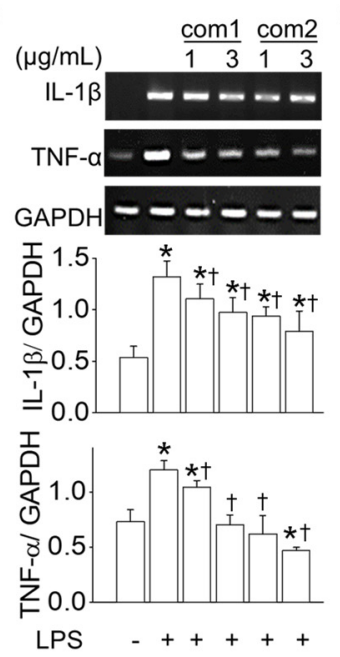

(b)
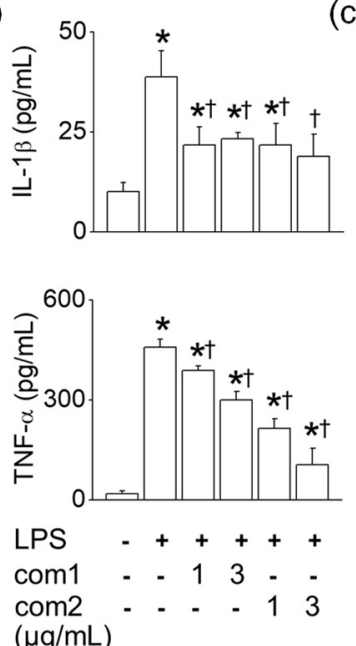

(c)

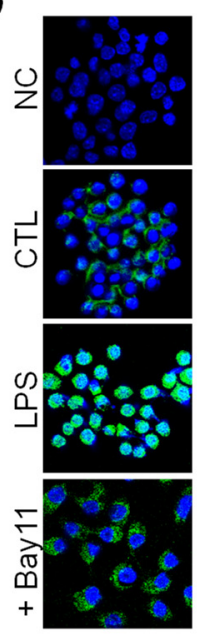

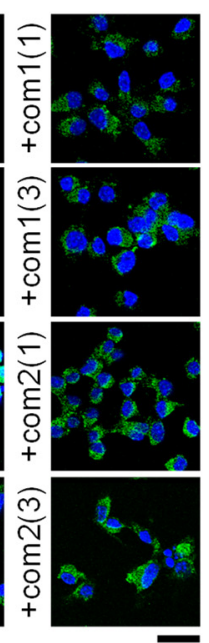

(d)

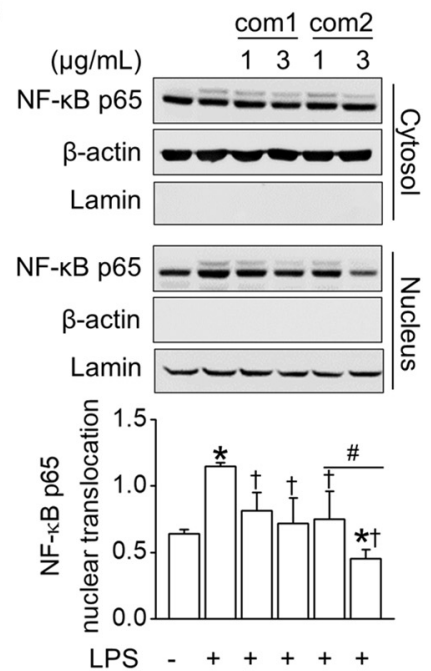

(e)

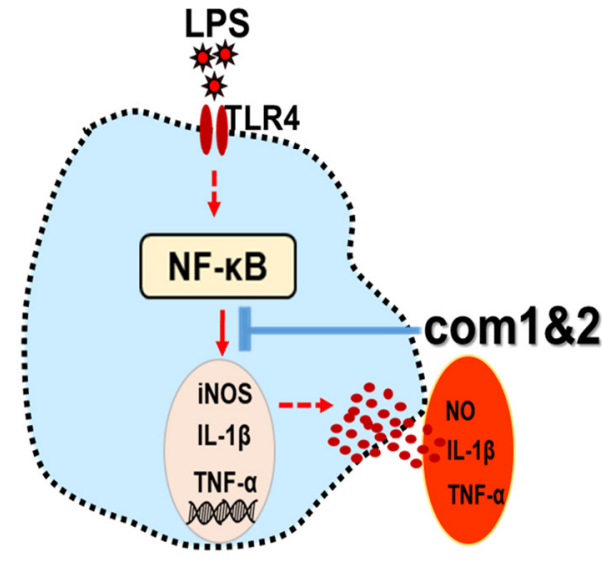

Figure 6. Suppression of pro-inflammatory cytokines through blocking NF- $\mathrm{BB}$ pathway by iridaltype triterpenoids in LPS-stimulated RAW264.7 cells. (a,b) Down-regulation of IL-1 $\beta$ and TNF- $\alpha$ mRNA expression and concentration by triterpenoids. (c,d) Suppression of LPS-induced nu-clear translocation of NF- $\mathrm{kB}$ p 65 upon treatment with triterpenoids confirmed by immunocyto-chemistry and Western blotting assay, respectively. NC represents negative control without primary antibody treatment. CTL, LPS, and Bay 11 represent control, lipopolysaccaride, and Bay11-7085, respectively. Bay11-7085 was used as an inhibitor of NF-кB p65 translocation. Scale bar, $20 \mu \mathrm{m}$. The plus and minus signs $(+$ and -$)$ indicate conditions with and without treatment, respectively. $(\mathbf{a}, \mathbf{b}, \mathbf{d}) * p<0.05$ compared to control (no treatment with LPS) ${ }^{\dagger} p<0.05$ com-pared to LPS alone treatment; ${ }^{\#} p<0.05$ compared to the $1 \mu \mathrm{g} / \mathrm{mL}$ of compound 2. (e) Schematic representation of anti-inflammatory signals in LPS-stimulated RAW264.7 cells by triterpenoids.

\section{Materials and Methods}

\subsection{General Experimental Procedures}

Open column chromatography was conducted using octadecylsilanized (ODS) silica gel (50 $\mu \mathrm{m}$, YMC Ltd., Kyoto, Japan). Preparative recycling high pressure liquid chromatography (HPLC) was carried out by LC-9130G NEXT (Jai Co., Ltd., Tokyo, Japan) using AQ C18 (S-10 $\mu \mathrm{m}, 12 \mathrm{~nm}, \mathrm{YMC}$, Kyoto, Japan) and Acclaim Polar Advantage II C-18 (S-5 $\mu \mathrm{m}, 12 \mathrm{~nm}$, Thermo Fisher Scientific, Waltham, MA, USA). ${ }^{1} \mathrm{H}$ and ${ }^{13} \mathrm{C}-\mathrm{NMR}$, as well as 2D NMR data were recorded by a Bruker AM500 spectrometer (Bruker, Billerica, MA, USA) using Acetone-d6 or Chloroform-d with tetramethylsilane (TMS) as an internal standard. UV spectra were measured using a DU650 spectrophotometer 
(Beckman Coulter, Brea, CA, USA). HRESIMS were carried out by a Vion (Waters, Milford, MA, USA). Specific rotation $([\alpha])$ was estimated using a P-2000 Digital Polarimeter (JASCO, Tokyo, Japan). Enzymatic assays were conducted by a SpectraMax M3 Multi-mode Microplate Reader (Molecular Devices, San Jose, CA, USA). All chemicals for analyses were of first grade. The root of B. chinensis [imported from China with permission of the Korean Food and Drug Administration (KFDA)] was purchased from a Korean pharmaceutical market (Jinju, Korea).

\subsection{Extraction and Isolation}

The dried roots of $B$. chinensis $(2.4 \mathrm{~kg})$ were extracted with methanol $(10 \mathrm{~L} \times 3)$ for 2 weeks at room temperature. The accumulated filtrate was evaporated to yield a pale yellow residue $(54 \mathrm{~g})$, which was suspended in water $(0.5 \mathrm{~L})$ and further fractionated successively with hexane $(1 \mathrm{~L} \times 3)$ and ethyl acetate $(1 \mathrm{~L} \times 3)$. The hexane fraction $(8.1 \mathrm{~g})$ was subjected to ODS silica gel $(200 \mathrm{~g})$ using a gradient of water to methanol (5:1 to 1:10, $v / v)$, which provided five fractions (A-E). HNE inhibitory fractions D-E (1.8 g) were portioned using a preparative HPLC with reversed silica gel CC $(250 \mathrm{~mm} \times 30 \mathrm{~mm}$, S-10 $\mu \mathrm{m}, 12 \mathrm{~nm}, \mathrm{YMC})$ and eluted using a gradient of methanol in water $(60 \%$ to $100 \%, v / v)$ at a rate of $10 \mathrm{~mL} / \mathrm{min}$, to yield thirty subfractions (D1-D30). Subfractions D6-D11 (180 mg) were further purified by recycling HPLC with reversed silica gel CC $(250 \mathrm{~mm} \times 30 \mathrm{~mm}$, S-5 $\mu \mathrm{m}, 12 \mathrm{~nm}$, Thermo Fisher Scientific, Waltham, MA, USA) using a isocratic elution with $\mathrm{H}_{2} \mathrm{O}: \mathrm{ACN}(3: 7, v / v)$ to give rise to compound $\mathbf{1}(7.2 \mathrm{mg})$ and compound 2 (68.3 $\left.\mathrm{mg}\right)$. Subfractions D24-D27 (95 $\mathrm{mg})$ provided $3(32.1 \mathrm{mg})$ through equal recycling HPLC with a reversed silicagel $\mathrm{CC}$ using an isocratic elution with $\mathrm{H}_{2} \mathrm{O}: \mathrm{ACN}(1: 9, v / v)$.

\subsubsection{Isoiridogermanal (1)}

Colorless oil. HRESIMS [M + Na] 474.3706 (calcd. for $\mathrm{C}_{30} \mathrm{H}_{50} \mathrm{O}_{4} 474.3709$ ). [ $\left.\alpha\right]_{D}^{25}+$ 36.7 (c 0.1, EtOH). ${ }^{1} \mathrm{H}-\mathrm{NMR}\left(500 \mathrm{MHz}\right.$, Acetone- $\left.d_{6}\right): \delta 1.10(3 \mathrm{H}, \mathrm{s}, \mathrm{H}-26), 1.16(3 \mathrm{H}, \mathrm{s}, \mathrm{H}-27)$, $1.18(1 \mathrm{H}, \mathrm{m}, \mathrm{H}-10 \mathrm{a}), 1.26$ (1H, m, H-24a), $1.32(1 \mathrm{H}, \mathrm{m}, \mathrm{H}-10 \mathrm{~b}), 1.40(1 \mathrm{H}, \mathrm{m}, \mathrm{H}-24 \mathrm{~b})$, 1.55 (3H, s, H-28), 1.60 (3H, s, H-30), 1.62 (3H, s, H-29), 1.65 (1H, m, H-8a), 1.68 (3H, s, H-22), 1.79 (1H, m, H-23a), 1.83 (3H, s, H-3), 1.86 (1H, m, H-11a), 1.87 (1H, m, H-8b), 1.96 (1H, m, H-11b), 2.02 (2H, m, J = 6.5 Hz, H-18), 2.03 (1H, m, H-23b), 2.07 (2H, m, H-19), 2.22 (2H, m, H-15), 2.55 (1H, br t, $J=13.8 \mathrm{~Hz}, \mathrm{H}-9 \mathrm{a}), 2.60$ (1H, td, $J=13.8,4.7 \mathrm{~Hz}, \mathrm{H}-9 \mathrm{~b}), 3.31$ $(1 \mathrm{H}$, br d, $J=11.1 \mathrm{~Hz}, \mathrm{H}-5), 3.61(2 \mathrm{H}, \mathrm{t}, J=6.4 \mathrm{~Hz}, \mathrm{H}-25), 3.92(1 \mathrm{H}, \mathrm{dd}, J=7.8,5.1 \mathrm{~Hz}, \mathrm{H}-14)$, $5.06(1 \mathrm{H}, \mathrm{m}, \mathrm{H}-20), 5.07$ (1H, m, H-16), $5.25(1 \mathrm{H}, \mathrm{t}, J=7.0 \mathrm{~Hz}, \mathrm{H}-12), 10.18(1 \mathrm{H}, \mathrm{s}, \mathrm{H}-1)$ (see Figures S1-S7 in Supplementary material).

\subsubsection{Iridobelamal A (2)}

Colorless oil. HRESIMS [M + Na] 474.3739 (calcd. for $\mathrm{C}_{30} \mathrm{H}_{50} \mathrm{O}_{4} 474.3709$ ). [ $\left.\alpha\right]_{D}^{25}+$ 42.0 (c 0.01, EtOH). ${ }^{1} \mathrm{H}-\mathrm{NMR}\left(500 \mathrm{MHz}\right.$, Acetone- $\left.d_{6}\right): \delta 1.09(3 \mathrm{H}, \mathrm{s}, \mathrm{H}-26), 1.13-1.32(2 \mathrm{H}$, m, H-10), 1.16 (3H, s, H-27), 1.33-1.41 (2H, m, H-24), 1.60 (3H, s, H-28), 1.60 (3H, s, H-30), 1.62-1.71 (1H, m, H-8a), 1.63 (3H, s, H-29), 1.68 (3H, s, H-22), 1.79 (1H, m, H-8b), 1.80 (1H, m, H-23a), 1.80 (3H, s, H-3), 1.90-1.96 (1H, m, H-11a), 1.99 (1H, m, H-11b), 2.02 (2H, m, H-18), 2.07 (2H, m, H-19), 2.10 (1H, m, H-23b), 2.13-2.33 (2H, m, H-15), 2.59 (1H, br t, $J=12.5 \mathrm{~Hz}, \mathrm{H}-9 \mathrm{a}), 2.79$ (1H, br d, $J=9.9 \mathrm{~Hz}, \mathrm{H}-5), 3.22(1 \mathrm{H}, \mathrm{br} \mathrm{d}, J=13.9 \mathrm{~Hz}, \mathrm{H}-9 \mathrm{~b}), 3.61$ (2H, td, $J=6.3,2.3 \mathrm{~Hz}, \mathrm{H}-25), 3.93(1 \mathrm{H}, \mathrm{dd}, J=7.5,5.1 \mathrm{~Hz}, \mathrm{H}-14), 5.06$ (1H, m, H-20), $5.07(1 \mathrm{H}, \mathrm{m}, \mathrm{H}-16), 5.26(1 \mathrm{H}, \mathrm{t}, J=6.8 \mathrm{~Hz}, \mathrm{H}-12), 10.24(1 \mathrm{H}, \mathrm{s}, \mathrm{H}-1)$ (see Figures S8-S14 in Supplementary material).

\subsubsection{Iridobelamal B (3)}

Colorless oil. HRESIMS [M + Na] 500.3514 (calcd. for $\mathrm{C}_{31} \mathrm{H}_{48} \mathrm{O}_{5}$ 500.3502). [ $\left.\alpha\right]_{D}^{25}+$ 50.4 (c 0.05, EtOH). ${ }^{1} \mathrm{H}-\mathrm{NMR}(500 \mathrm{MHz}$, Chloroform- $d)$ : $\delta 1.3-1.4$ (2H, m, H-24), 1.31 (3H, s, H-27), 1.40 (1H, dd, J = 6.1, 12.0 Hz, H-10a), 1.62 (3H, s, H-30), 1.69 (3H, s, H-22), $1.71(1 \mathrm{H}$, m, H-8a), 1.79 (3H, br s, H-3), 1.80 (3H, s, H-28), 1.80-1.86 (1H, m, H-8b), 1.82 (3H, s, H-29), $1.93(1 \mathrm{H}, \mathrm{dd}, J=8.3,13.6 \mathrm{~Hz}, \mathrm{H}-10 \mathrm{~b}), 1.98-2.08$ (2H, m, H-23), 2.10-2.14 (2H, m, H-19), 2.54 
(1H, br d, J = 12.0 Hz, H-9a), 2.69 (1H, m, H-9b), 3.39 (3H, s, 26-OMe), 3.61 (2H, td, J = 3.0, $6.3 \mathrm{~Hz}, \mathrm{H}-25), 3.66(1 \mathrm{H}, \mathrm{brd}, J=12.4 \mathrm{~Hz}, \mathrm{H}-5), 4.88(1 \mathrm{H}, \mathrm{dd}, J=8.2,16.0 \mathrm{~Hz}, \mathrm{H}-11), 5.11$ (1H, m, H-20), $5.11(1 \mathrm{H}, \mathrm{s}, \mathrm{H}-26), 5.48(1 \mathrm{H}, \mathrm{br} \mathrm{d}, J=8.7 \mathrm{~Hz}, \mathrm{H}-12), 5.91(1 \mathrm{H}, \mathrm{d}, J=10.8 \mathrm{~Hz}$, H-16), $6.16(1 \mathrm{H}, \mathrm{d}, J=15.3 \mathrm{~Hz}, \mathrm{H}-14), 6.43(1 \mathrm{H}, \mathrm{dd}, J=10.8,15.3 \mathrm{~Hz}, \mathrm{H}-15), 10.24(1 \mathrm{H}, \mathrm{s}$, H-1) (see Figures S15-S21 in Supplementary material).

\subsection{Inhibitory Effects against Human Neutrophil Elastase}

Human neutrophil elastase (EC 3. 4. 21. 37) (Sigma-Aldrich, St. Louis, MO, USA) activity was measured in accordance with the previous description [27] with subtle modification, by observing the formation of $p$-nitroaniline after the hydrolysis of $N$-methoxysuccinyl-AlaAla-Pro-Val- $p$-nitro anilide at $405 \mathrm{~nm}$. The inhibitors were dissolved in dimethyl sulfoxide (DMSO) and diluted to a few concentrations. In brief, in a 96-well plate, $10 \mu \mathrm{L}$ of inhibitor solution and $40 \mu \mathrm{L}$ of $1.5 \mathrm{mM}$ of MeOSuc-AAPV- $p$ NA were added as a substrate in the $0.02 \mathrm{mM}$ Tris-HCl buffer solutions ( $\mathrm{pH}$ 8.0). Then, $20 \mu \mathrm{L}$ of human neutrophil elastase $(0.2 \mathrm{unit} / \mathrm{mL})$ was added to the mixture. The test mixtures were incubated and mixed for $15 \mathrm{~min}$ at room temperature and then screened at $405 \mathrm{~nm}$ for $30 \mathrm{~min}$ every $30 \mathrm{~s}$. Inhibitory activities were further characterized by determining the concentration required to inhibit $50 \%$ of the enzyme activity $\left(\mathrm{IC}_{50}\right)$, which was calculated using the following Equation (1), where $[\mathrm{I}]$ is the concentration of inhibitor.

$$
\text { Activity }(\%)=100\left[1 /\left(1+\left([\mathrm{I}] / \mathrm{IC}_{50}\right)\right)\right] \text {. }
$$

The modalities of HNE inhibition were estimated in experiments using particular concentrations of the substrates and inhibitors, respectively. The Michaelis-Menten constant $\left(K_{\mathrm{m}}\right)$ and maximal velocity $\left(V_{\max }\right)$ were investigated by a Lineweaver-Burk plot. The $K_{I}$, dissociation constants for inhibitor binding to the free enzyme were calculated using a Dixon plot. Equations (2)-(4) are representatives for deriving the aforementioned parameters.

$$
\begin{gathered}
\frac{1}{V}=\frac{K_{\mathrm{m}}}{V_{\max }}\left(1+\frac{[I]}{K_{i}}\right) \times \frac{1}{S}+\frac{1}{V_{\max }} \\
\text { Slop }=\frac{K_{\mathrm{m}}}{K_{i} V_{\max }}[I]+\frac{K_{\mathrm{m}}}{V_{\max }} \\
\text { Intercept }=\frac{1}{K_{i} V_{\max }}[I]+\frac{1}{V_{\max }} .
\end{gathered}
$$

\subsection{Fluorescence Quenching Measurements}

To measure fluorescence from the HNE enzyme, $10 \mu \mathrm{L}$ of 0.01 unit/mL enzyme solution with $180 \mu \mathrm{L}$ of Tris- $\mathrm{HCl}$ buffer $(0.02 \mathrm{mM})$ was accurately added into the 96-well black immunoplates. Then, $10 \mu \mathrm{L}$ of incremental concentrations (7.8-31.2 $\mu \mathrm{M})$ of inhibitors were added into each well. All fluorescence spectra were measured from 280 to $400 \mathrm{~nm}$ with emission slits regulated to $2.0 \mathrm{~nm}$, and the excitation wavelength was $260 \mathrm{~nm}$. The Stern-Volmer quenching constant $\left(K_{\mathrm{SV}}\right)$ was calculated using Equation (5). All experiments were conducted in triplicate, and the mean values were calculated [28].

$$
F_{0}-F=1+K_{\mathrm{SV}}[\mathrm{Q}]
$$

where $F_{0}$ and $F$ are the fluorescence intensities in the absence and presence of quencher $(Q)$. $K_{\mathrm{SV}}$ is the Stern-Volmer quenching constant $\left[\mathrm{LM}^{-1}\right]$. For static quenching, the correlation between the fluorescence intensity and the concentration of quencher for the series of reactions can be estimated by Equation (6) [29].

$$
\log \left[\left(F_{0}-F\right) / F\right]=\log K_{\mathrm{A}}+n \log [\mathrm{Q}]_{\mathrm{f}} .
$$


$F_{0}$ and $F$ are the fluorescence intensities in the absence and presence of inhibitor; $K_{\mathrm{A}}$ is the binding constant; $n$ is the number of binding sites of the enzyme; $Q_{f}$ is the concentration of inhibitor.

\subsection{Cell Culture and Cell Viability Assay}

The mouse macrophage cell line RAW264.7 was obtained from the American Type Culture Collection (ATCC, Manassas, VA, USA). The cells were cultured in DMEM supplemented with $10 \%$ fetal bovine serum (FBS), penicillin $(100 \mathrm{U} / \mathrm{mL})$, and streptomycin $(100 \mu \mathrm{g} / \mathrm{mL})$ at $37^{\circ} \mathrm{C}$ with $5 \% \mathrm{CO}_{2}$. The medium was replaced every 2 days. After treatment with chemicals, the cell morphological changes were observed under a microscope and images are captured before cell viability assay.

Cell viability was determined calorimetrically using a 3-(4,5-dimethylthiazole-2-yl)2,5-diphenyl tetrazolium bromide (MTT) reagent $(5 \mathrm{mg} / \mathrm{mL}$ in phosphate buffered saline (PBS), Duchefa Biochemie, Haarlem, The Netherlands). The MTT assay procedures were performed as described previously [30]. Briefly, a 24 -well plate $\left(5 \times 10^{4}\right.$ cells / well $)$ was seeded with RAW264.7, a mouse macrophage cell line. After $24 \mathrm{~h}$ of chemical treatment, each well was filled with $20 \mu \mathrm{L}$ of $5 \mathrm{mg} / \mathrm{mL}$ MTT solution $(0.1 \mathrm{mg} / \mathrm{mL})$ and incubated for $4 \mathrm{~h}$. After aspirating the supernatants, the formazan crystals in each well were dissolved in $200 \mu \mathrm{L}$ of dimethyl sulfoxide (DMSO) for $30 \mathrm{~min}$ at $37^{\circ} \mathrm{C}$, and the 24 -well plates were read at $570 \mathrm{~nm}$ with a microplate reader (Bio-Rad, Hercules, CA, USA). Data are expressed as a percentage of viable cells compared with the control.

\subsection{RNA Isolation and Reverse Transcriptase (RT)-Polymerase Chain Reaction (PCR)}

Total RNA was isolated from cultured RAW264.7 cells using TRIzol reagent (Ambion ${ }^{\circledR}$, Carlsbad, CA, USA) according to the manufacturer's instructions. First strand cDNA was synthesized from the total RNA $(3 \mu \mathrm{g})$ using oligo dT (DiaStar RT Kit, SolGent, Daejeon, Korea) and was used as a template for PCR amplification with G-Taq polymerase (Cosmogenetech, Seoul, Korea). The first-strand cDNA was quantified using a spectrophotometer (NanoDrop ${ }^{\circledR}$ ND-1000, NanoDrop Technologies, Wilmington, DC, USA). The quantified cDNA was used as a template. PCR assay was performed with specific primers for inducible nitric oxide (iNOS), IL-1 $\beta$, and TNF- $\alpha$. The primer sequences are listed in Table S1. The PCR steps included initial denaturation at $94{ }^{\circ} \mathrm{C}$ for $5 \mathrm{~min}$, then 28 cycles at $94{ }^{\circ} \mathrm{C}$ for $30 \mathrm{~s}, 57^{\circ} \mathrm{C}$ for $30 \mathrm{~s}$, and $72{ }^{\circ} \mathrm{C}$ for $30 \mathrm{~s}$, and a final extension step at $72{ }^{\circ} \mathrm{C}$ for $10 \mathrm{~min}$. The amplified PCR products were separated in 1.5\% agarose gel, and the gel was stained with ethidium bromide. The bands were visualized using the iBright ${ }^{\mathrm{TM}}$ CL1500 imaging system (Thermo Scientific Fisher/Life Technologies Holdings Pte Ltd., Singapore). The DNA fragments were directly sequenced with the ABI PRISM ${ }^{\circledR}$ 3100-Avant Genetic Analyzer (Applied Biosystems, Carlsbad, CA, USA).

\subsection{Measurement of Nitrite Levels}

Nitrite levels were determined using the Griess method, as described previously (Jeong et al., 2016). Briefly, RAW264.7 cells $\left(5 \times 10^{4}\right.$ cells/well) were cultured in a 24-well plate. The cells were pretreated with triterpenoids $(1$ or $3 \mu \mathrm{g} / \mathrm{mL}) 2 \mathrm{~h}$ prior to lipopolysaccharides (LPS, $1 \mu \mathrm{g} / \mathrm{mL}$ ) treatment for $16 \mathrm{~h}$. Supernatants were collected and centrifuged at $2451 \times g$ for $10 \mathrm{~min}$. The $(50 \mu \mathrm{L})$ of supernatants were mixed with equal volumes of Griess reagent ( $1 \%$ sulfanilamide, $0.1 \%$ n-l-naphthylethy-lenediamine dihydrochloride, and $2 \%$ phosphoric acid), and incubated for $10 \mathrm{~min}$. The optical density was measured at $550 \mathrm{~nm}$, and the nitrite levels were calculated from a standard curve generated from sodium nitrite.

\subsection{Measurement of Cytokines Concentration}

RAW264.7 cell $\left(2 \times 10^{5}\right.$ cells/well) were cultured in a 6-well plate for $24 \mathrm{~h}$ and treated with compounds ( 1 or $3 \mu \mathrm{g} / \mathrm{mL}$ ) $2 \mathrm{~h}$ prior to LPS treatment, followed by LPS $(1 \mu \mathrm{g} / \mathrm{mL})$ for $16 \mathrm{~h}$. The concentration of pro-inflammatory cytokines in the collected 
supernatant was quantified using an ELISA kit (R\&D system, Minneapolis, MN, USA) according to the manufacturer's instructions. Briefly, $50 \mu \mathrm{L}$ of assay diluent, sample, and standards were added to the ELISA well plate, which were pre-coated with anti-mouse IL-1 $\beta$ and TNF- $\alpha$ antibody. The plates were then covered with adhesive strip, agitated, and incubated for $2 \mathrm{~h}$ at room temperature. The ELISA well-plate was washed five times with a wash buffer, then $100 \mu \mathrm{L}$ of mouse IL- $1 \beta$ and TNF- $\alpha$ conjugates was added and incubated at room temperature for $2 \mathrm{~h}$. The plate was washed five times, $100 \mu \mathrm{L}$ of substrate solution was added to each well, and incubated for $30 \mathrm{~min}$ in the dark. The reaction was quenched by the addition of $100 \mu \mathrm{L}$ stop solution to each well, and the absorbance was read $450 \mathrm{~nm} / 570 \mathrm{~nm}$ with an ELISA reader (Molecular Devices, Sunnyvale, CA, USA).

\subsection{Immunocytochemistry}

RAW264.7 cells cultured on round cover slips coated with poly-L-lysine were treated with triterpenoids ( 1 or $3 \mu \mathrm{g} / \mathrm{mL}) 2 \mathrm{~h}$ prior to LPS treatment, followed by LPS $(1 \mu \mathrm{g} / \mathrm{mL})$ for $16 \mathrm{~h}$. The cells were washed with $1 \mathrm{x}$ phosphate buffered saline (PBS) and fixed with $4 \%$ paraformaldehyde for $30 \mathrm{~min}$. After washing the fixed cells with PBS, the cells were permeabilized with a blocking buffer (1\% normal goat serum and $0.2 \%$ Triton X-100 in PBS) for $30 \mathrm{~min}$ at room temperature, and were incubated with an anti-NF-kB p65 antibody (1:200 dilution, Cell Signaling Technology, Danvers, MA, USA) at $4{ }^{\circ} \mathrm{C}$ overnight. After three washes in PBS, the cells were incubated in the dark for $1 \mathrm{~h}$ with the mixture of FITCconjugated anti-rabbit IgG fluorescent secondary antibody diluted at 1:500 in PBS. Finally, the cells were stained with $2 \mu \mathrm{g} / \mathrm{mL}$ Hoechst for nuclei staining. The cells were washed with PBS, wet-mounted on glass slides, and observed using a confocal laser-scanning microscope (Olympus, Tokyo, Japan). The negative control (NC) was analyzed by omitting the primary antibody.

\subsection{Western Blot Analysis with Nuclear and Cytoplasmic Fractions}

RAW264.7 cells were homogenized in a hypotonic lysis buffer and centrifuged at $142 \times \mathrm{g}$ for $5 \mathrm{~min}$ at $4{ }^{\circ} \mathrm{C}$. The resulting pellets and supernatants were used for the isolation of nuclear and cytosoplasmic fraction, respectively. The pellets were incubated on ice for $5 \mathrm{~min}$ with a nuclear isolation buffer and were spun at $142 \times g$ using Eppendorf centrifuge $5424 \mathrm{R}$ at $4^{\circ} \mathrm{C}$ for $5 \mathrm{~min}$. The resulting pellets were incubated on ice for $30 \mathrm{~min}$ with $2 \%$ Triton nuclear isolation buffer and were spun at $12,448 \times g$ at $4{ }^{\circ} \mathrm{C}$ for $15 \mathrm{~min}$. For the cytosolic fraction, the resulting supernatants in the hypotonic lysis buffer were transferred to a new $1.5 \mathrm{~mL}$ tube and spun at $15,401 \times g$ for $15 \mathrm{~min}$ at $4{ }^{\circ} \mathrm{C}$. The resulting supernatants were centrifuged at $100,000 \times g$ at $4{ }^{\circ} \mathrm{C}$ for $60 \mathrm{~min}$ in an ultracentrifuge (TLA 100.3; Optima MAX-XP, Beckman Coulter, Inc., Brea, CA, USA). The proteins of nuclear and cytosolic fractions were separated on $8 \%$ SDS-PAGE gel and blotted onto polyvinylidene difluoride membranes. Equal amounts of $35 \mu \mathrm{g}$ were analyzed by Western blotting. Briefly, the membranes were blocked with $5 \%$ fat-free dry milk and then incubated with the anti-NF-kB p65 polyclonal antibody (1:1000 dilution; Cell Signaling Technology), and anti- $\beta$-actin monoclonal antibodies (1:5000 dilution). The primary antibody incubation was followed by incubation with a secondary horseradish peroxidase-conjugated goat antirabbit or goat anti-mouse antibody at 1:5000 dilution (Assay Designs, Ann Arbor, MI, USA). Immunopositive bands were visualized by iBright ${ }^{\mathrm{TM}}$ CL1500 Imaging System (Thermo Scientific Fisher/Life Technologies Holdings Pte Ltd., Waltham, MA, USA). The cytosolic and nuclear fractions were verified to be free of contaminating nucleus and cytosol by immunoblotting for the cytosolic marker $\beta$-actin and the nuclear marker lamin, respectively.

\subsection{Statistical Analysis}

One-way ANOVA with post hoc comparisons using the Bonferroni test were used to analyze the difference among groups (OriginPro2020, OriginLab Corp. Northampton, MA, USA). Data were presented as the mean \pm S.D., and significance was set at $p<0.05$. 


\section{Conclusions}

B. chinensis has been considered a representative medicinal plant for inflammatory diseases such as bronchitis, asthma, and sore throat. Iridal-type triterpenoids (1-3) were found to effectively inhibit the pro-inflammatory enzyme, human neutrophil elastase (HNE). The Stern-Volmer quenching constant $\left(K_{\mathrm{sv}}\right)$ and the binding constant $\left(K_{\mathrm{A}}\right)$ were in accordance with inhibitory potencies $\left(\mathrm{IC}_{50}\right)$. The HNE enzyme had only a single binding site for iridal-type triterpenoids. The spiro-type compound $\mathbf{3}$ showed a $\mathbf{2}-\mathbf{3}$ fold better HNE inhibition and binding affinities than the monocyclic ones (1 and 2). Among them, isoiridogermanal (1) and iridobelamal A (2) effectively suppressed the expression of proinflammatory cytokines, such as iNOS, IL- $1 \beta$ and TNF- $\alpha$ through blocking the NF- $\mathrm{kB}$ pathway. In summary, iridal-type triterpenoids might be prime phytochemicals for the anti-inflammation potential of $B$. chinensis.

Supplementary Materials: The following are available online, Figures S1-S7: NMR and HRESIMS data of compound 1, Figures S8-S14: NMR and HRESIMS data of compound 2, Figures S15-S21: NMR and HRESIMS data of compound 3, Table S1: Primer sequences used for RT-PCR.

Author Contributions: Conceptualization, J.H.K.; methodology, Y.J.B., A.B. and M.M.N.; validation, J.H.K. and Y.J.B.; formal analysis, A.B., M.M.N. and D.K.; investigation, J.H.K., S.S.K. and K.H.P.; data curation, J.H.K. and Y.J.B.; writing-original draft preparation, J.H.K.; writing-review and editing, K.H.P. and D.K.; supervision, D.K., S.S.K. and K.H.P. All authors have read and agreed to the published version of the manuscript.

Funding: This research was supported by the Bio and Medical Technology Development Program of the National Research Foundation (NRF) funded by the Ministry of Science and ICT (No. NRF2020M3A9I3038523) and Rural Development Administration (PJ015732), Republic of Korea. The BK21 plus program supported scholarships for all students. This research received no external funding.

Institutional Review Board Statement: Not applicable.

Informed Consent Statement: Not applicable.

Data Availability Statement: The data presented in this study are available on request from the corresponding author.

Conflicts of Interest: The authors declare no conflict of interest. The funders had no role in the design of the study; in the collection, analyses, or interpretation of data; in the writing of the manuscript, or in the decision to publish the results.

Sample Availability: Samples of the compounds 1-3 are not available from the authors.

\section{References}

1. Xin, R.; Zheng, J.; Cheng, L.; Peng, W. Belamcanda chinensis (L.) DC: Ethnopharmacology, Phytochemistry and Pharmacology of An Important Traditional Chinese Medicine. Afr. J. Tradit. Complement. Altern. Med. 2015, 12, 39-70. [CrossRef]

2. Woźniak, D.; Matkowski, A. Belamcandae chinensis rhizoma-A review of phytochemistry and bioactivity. Fitoterapia 2015, 107, 1-14. [CrossRef] [PubMed]

3. Zhang, L.; Wei, K.; Xu, J.; Yang, D.; Zhang, C.; Wang, Z.; Li, M. Belamcanda chinensis (L.) DC-An ethnopharmacological, phytochemical and pharmacological review. J. Ethnopharmacol. 2016, 186, 1-13. [CrossRef] [PubMed]

4. Takahashfi, K.; Hoshino, Y.; Suzuki, S.; Hano, Y.; Nomura, T. Iridals from Iris tectorum and Belamcanda chinensis. Phytochemistry 2000, 53, 925-929. [CrossRef]

5. Taylor, S.; Dirir, O.; Zamanian, R.T.; Rabinovitch, M.; Thompson, A.A.R. The role of neutrophils and neutrophil elastase in pulmonary arterial hypertension. Front. Med. 2018, 5, 217. [CrossRef]

6. Bardoel, B.W.; Kenny, E.F.; Sollberger, G.; Zychlinsky, A. The balancing act of neutrophils. Cell Host Microbe 2014, 15, 526-536. [CrossRef]

7. Crocetti, L.; Quinn, M.T.; Schepetkin, I.A.; Giovannoni, M.P. A patenting perspective on human neutrophil elastase (HNE) inhibitors (2014-2018) and their therapeutic applications. Expert Opin. Ther. Pat. 2019, 29, 555-578. [CrossRef]

8. Lee, W.L.; Downey, G.P. Leukocyte elastase: Physiological functions and role in acute lung injury. Am. J. Respir. Crit. Care Med. 2001, 164, 896-904. [CrossRef] 
9. Hussain, T.; Tan, B.; Yin, Y.; Blachier, F.; Tossou, M.C.B.; Rahu, N. Oxidative Stress and Inflammation: What Polyphenols Can Do for Us? Oxid. Med. Cell. Longev. 2016, 2016, 7432797. [CrossRef]

10. Boutten, A.; Dehoux, M.S.; Seta, N.; Ostinelli, J.; Venembre, P.; Crestani, B.; Dombret, M.C.; Durand, G.; Aubier, M. Compartmentalized IL-8 and elastase release within the human lung in unilateral pneumonia. Am. J. Respir. Crit. Care Med. 1996, 153, 336-342. [CrossRef]

11. Thulborn, S.J.; Mistry, V.; Brightling, C.E.; Moffitt, K.L.; Ribeiro, D.; Bafadhel, M. Neutrophil elastase as a biomarker for bacterial infection in COPD. Respir. Res. 2019, 20, 170. [CrossRef] [PubMed]

12. Dollery, C.M.; Owen, C.A.; Sukhova, G.K.; Krettek, A.; Shapiro, S.D.; Libby, P. Neutrophil elastase in human atherosclerotic plaques production by macrophages. Circulation 2003, 107, 2829-2836. [CrossRef]

13. Muley, M.M.; Reid, A.R.; Botz, B.; Bölcskei, K.; Helyes, Z.; McDougall, J.J. Neutrophil elastase induces inflammation and pain in mouse knee joints via activation of proteinase-activated receptor-2. Br. J. Pharmacol. 2016, 173, 766-777. [CrossRef]

14. Xu, R.; Huang, H.; Zhang, Z.; Wang, F.S. The role of neutrophils in the development of liver diseases. Cell. Mol. Immunol. 2014, 11, 224-231. [CrossRef]

15. Tsai, Y.F.; Yu, H.P.; Chang, W.Y.; Liu, F.C.; Huang, Z.C.; Hwang, T.L. Sirtinol Inhibits Neutrophil Elastase Activity and Attenuates Lipopolysaccharide-Mediated Acute Lung Injury in Mice. Sci. Rep. 2015, 5, 8347. [CrossRef]

16. Ryu, H.W.; Kim, K.O.; Yuk, H.J.; Kwon, O.K.; Kim, J.H.; Kim, D.Y.; Na, M.K.; Ahn, K.S.; Oh, S.R. The constituent, anti-inflammation, and human neutrophil elastase inhibitory activity of Gnaphalium affine. J. Funct. Foods 2016, 27, 674-684. [CrossRef]

17. Henriksen, P.A. The potential of neutrophil elastase inhibitors as anti-inflammatory therapies. Curr. Opin. Hematol. 2014, 21, 23-28. [CrossRef]

18. Fürst, R.; Zündorf, I. Plant-derived anti-inflammatory compounds: Hopes and disappointments regarding the translation of preclinical knowledge into clinical progress. Mediat. Inflamm. 2014, 2014, 146832. [CrossRef] [PubMed]

19. Checker, R.; Sandur, S.K.; Sharma, D.; Patwardhan, R.S.; Jayakumar, S.; Kohli, V.; Sethi, G.; Aggarwal, B.B.; Sainis, K.B. Potent anti-inflammatory activity of ursolic acid, a triterpenoid antioxidant, is mediated through suppression of NF- $\mathrm{KB}, \mathrm{AP}-1$ and NF-AT. PLoS ONE 2012, 7, e31318. [CrossRef]

20. Zhang, C.L.; Wang, Y.; Liu, Y.F.; Liang, D.; Hao, Z.Y.; Luo, H.; Zhang, Q.J.; Shi, G.R.; Chen, R.Y.; Cao, Z.Y.; et al. Cytotoxic iridal-type triterpenoids from Iris tectorum. Tetrahedron 2015, 71, 5579-5583. [CrossRef]

21. Takahashi, K.; Suzuki, S.; Hano, Y.; Nomura, T. Protein kinase C activation by iridal type triterpenoids. Biol. Pharm. Bull. 2002, 25, 432-436. [CrossRef]

22. Fang, R.; Houghton, P.J.; Hylands, P.J. Cytotoxic effects of compounds from Iris tectorum on human cancer cell lines. J. Ethnopharmacol. 2008, 118, 257-263. [CrossRef] [PubMed]

23. Topic, A.; Milovanovic, V.; Lazic, Z.; Ivosevic, A.; Radojkovic, D. Oxidized Alpha-1-Antitrypsin as a Potential Biomarker Associated with Onset and Severity of Chronic Obstructive Pulmonary Disease in Adult Population. COPD J. Chronic Obstr. Pulm. Dis. 2018, 15, 472-478. [CrossRef] [PubMed]

24. Sinha, S.; Watorek, W.; Karr, S.; Giles, J.; Bode, W.; Travis, J. Primary structure of human neutrophil elastase. Proc. Natl. Acad. Sci. USA 1987, 84, 2228-2232. [CrossRef]

25. Van Amersfoort, E.S.; Van Berkel, T.J.C.; Kuiper, J. Receptors, mediators, and mechanisms involved in bacterial sepsis and septic shock. Clin. Microbiol. Rev. 2003, 16, 379-414. [CrossRef]

26. Ryu, J.H.; Sung, J.; Xie, C.; Shin, M.K.; Kim, C.W.; Kim, N.G.; Choi, Y.J.; Choi, B.D.; Kang, S.S.; Kang, D. Aplysia kurodai-derived glycosaminoglycans increase the phagocytic ability of macrophages via the activation of AMP-activated protein kinase and cytoskeletal reorganization in RAW264.7 cells. J. Funct. Foods 2016, 27, 122-130. [CrossRef]

27. Kim, J.Y.; Wang, Y.; Uddin, Z.; Song, Y.H.; Li, Z.P.; Jenis, J.; Park, K.H. Competitive neutrophil elastase inhibitory isoflavones from the roots of Flemingia philippinensis. Bioorg. Chem. 2018, 78, 249-257. [CrossRef]

28. Li, Z.P.; Kim, J.Y.; Ban, Y.J.; Park, K.H. Human neutrophil elastase (HNE) inhibitory polyprenylated acylphloroglucinols from the flowers of Hypericum ascyron. Bioorg. Chem. 2019, 90, 103075. [CrossRef]

29. Kim, J.H.; Jang, D.H.; Lee, K.W.; Kim, K.D.; Shah, A.B.; Zhumanova, K.; Park, K.H. Tyrosinase Inhibition and Kinetic Details of Puerol A Having But-2-Enolide Structure from Amorpha fruticosa. Molecules 2020, 25, 2344. [CrossRef]

30. Jeong, Y.Y.; Ryu, J.H.; Shin, J.H.; Kang, M.J.; Kang, J.R.; Han, J.; Kang, D. Comparison of anti-oxidant and anti-inflammatory effects between fresh and aged black garlic extracts. Molecules 2016, 21, 430. [CrossRef] [PubMed] 